\title{
ANALISIS ETIKA BISNIS ISLAM TERHADAP PRAKTIK PEMBULATAN HARGA PADA JUAL BELI KARET
}

\author{
Mutia Sumarni \\ Fakultas Ekonomi dan Bisnis Islam IAIN Langsa \\ meutiasumarni@gmail.com
}

\begin{abstract}
This study describes the practice of rounding prices on buying and selling rubber in Medang Ara village, Karang Baru District. The purpose of this study was to determine the practice of price rounding on the sale and purchase of rubber and to determine the analysis of Islamic business ethics on the practice of rounding prices on buying and selling rubber in the village of Medang Ara, Karang Baru District. The type of research used is field research. Data collection techniques through observation, interviews and documentation, as well as data analysis techniques with a qualitative descriptive approach.Based on the results of the study note that the price rounding done by Medang Ara village rubber agent is rounding down prices. The agent did this rounding because there was no change which made it difficult to pay for the rubber and the agent thought that rounding was a common thing and was known by farmers, so farmers would be sincere if the money was rounded up. In addition, the price rounding done by an agent is contrary to the basic provisions in Islamic business ethics, namely unity, balance, free will, responsibility and truth, and rounding the price is also contrary to the principles in Islamic business ethics such as honesty and transparency in setting prices.
\end{abstract}

Keywords: Rounding price, Buying and selling 


\begin{abstract}
Abstrak
Penelitian ini menjelaskan tentang praktik pembulatan harga pada jual beli karet di desa Medang Ara Kecamatan Karang Baru.Adapun tujuan penelitian ini adalah untuk mengetahui praktik pembulatan harga pada jual beli karet dan untuk mengetahui analisis etika bisnis Islam terhadap praktik pembulatan harga pada jual beli karet di desa Medang Ara Kecamatan Karang Baru.Jenis penelitian yang digunakan adalah penelitian lapangan (field research).Teknik pengumpulan data melalui metode observasi, wawancara dan dokumentasi, serta teknik analisis data dengan pendekatan deskriptif kualitatif.Berdasarkan hasil penelitian diketahui bahwa pembulatan harga yang dilakukan agen karet desa Medang Ara adalah pembulatan harga yang kebawah. Agen melakukan pembulatan ini karena ketiadaan uang receh yang membuat sulitnya dalam membayar karet tersebut dan agen mengira pembulatan ini adalah hal yang lazim dan sudah diketahui oleh para petani, sehingga petani akan ikhlas jika uangnya dibulatkan. Selain itu pembulatan harga yang dilakukan oleh agen bertentangan dengan ketentuan dasar dalam etika bisnis Islam yaitu kesatuan, keseimbangan, kehendak bebas, tanggung jawab dan kebenaran, serta pembulatan harga ini juga bertentangan dengan prinsip-prinsip dalam etika bisnis Islam seperti kejujuran dan transparansi dalam menetapkan harga.
\end{abstract}

Kata kunci: Pembulatan harga, Jual beli 


\section{PENDAHULUAN}

Di dalam Islam, manusia diwajibkan untuk berusaha agar mendapatkan rezeki guna memenuhi kebutuhan kehidupannya.Oleh karena itu setiap manusia memerlukan harta untuk mencukupi segala kebutuhan tersebut. Dengan begitu manusia akan selalu berusaha memperoleh harta kekayaan itu. Salah satu usaha untuk memperolehnya adalah dengan bekerja, sedangkan salah satu bentuk bekerja adalah berdagang atau berbisnis.

Bagi seorang manusia, bisnis adalah salah satu hal yang dapat dilakukan dalam memperoleh harta untuk memenuhi kebutuhan hidupnya. Menurut Skinner, bisnis adalah pertukaran barang, jasa atau uang yang saling menguntungkan atau memberikan manfaat. Secara sederhana, bisnis adalah semua kegiatan yang dilakukan seseorang atau lebih yang terorganisasi dalam mencari laba melalui penyediaan produk yang dibutuhkan oleh masyarakat (Tantri, 2010:4)

Selama ini banyak orang memahami bisnis adalah bisnis, yang tujuan utamanya memperoleh keuntungan sebanyak-banyaknya. Hukum ekonomi klasik yang mengendalikan modal sekecil mungkin dan mengeruk keuntungan sebesar mungkin telah menjadikan para "pelaku bisnis" menghalalkan segala cara untuk meraih keuntungan, mulai dari memperoleh bahan baku, bahan yang digunakan, tempat produksi, tenaga kerja pengelolaannya, dan pemasarannya dilakukan seefektif dan seefesien mungkin. Hal ini tidak mengherankan jika para pelaku bisnis jarang memperhatikan tanggung jawab sosial dan mengabaikan etika bisnis islam

Etika bisnis bertugas melakukan perubahan kesadaran masyarakat tentang bisnis dengan memberikan suatu pemahaman atau cara pandang baru, yakni bahwa bisnis tidak terpisah dari etika (Muhammad,2004:4). Etika dalam bisnis Islam mengacu pada dua sumber utama yaitu Al-Qur'an dan Sunnah Nabi SAW. Dua sumber ini merupakan sumber dari segala sumber yang ada, membimbing dan mengarahkan semua perilaku individu atau kelompok dalam menjalankan ibadah, perbuatan atau aktivitas umat Islam. Jadi etika bisnis Islam adalah norma dan tuntunan atau ajaran yang menyangkut sistem kehidupan individu dan atau masyarakat dalam menjalankan kegiatan usaha atau bisnis, dimana harus selalu mengikuti aturan yang ditetapkan dalam Islam sebagai acuan oleh siapapun dalam aktivitas bisnis.

Karena itu apabila dalam praktiknya para pelaku bisnis bersikap jujur dalam timbangan, jujur dalam beriklan, menghindari monopoli dan nepotisme, bersikap adil, ramah pada konsumen,menjauhi pembajakan dalam bentuk apapun, memperhatikan pelestarian dan kebersihan lingkungan, bersikap baik sesama pesaing, dan lain sebagainya, maka berarti mereka telah mempraktikkan norma-norma moral yang 
terpuji. Atau dalam Islam, sederet norma ini dikenal dengan istilah akhlak yang "terpuji”. Jika Memang demikian, ini berarti bahwa nilai-nilai dan norma-norma akhlak benar-benar mempunyai makna dalam kehidupan, khususnya dalam dunia bisnis yang sangat rentan dengan prilaku menyimpang yang sangat dibenci dalam Islam (Djakfar,2008:77).

Agar terhindar dari prilaku menyimpang tersebut, maka perlu kita teladani keberhasilan Nabi Muhammad SAW dalam hal berbisnis atau jual beli. Dalam praktek bisnisnya, beliau menerapkan beberapa etika bisnis, antara lain yaitu: Pertama, kejujuran. Dalam melakukan transaksi bisnis Rasulullah menggunakan kejujuran sebagai etika dasar.Kedua yaitu amanah, ketiga tepat menimbang, keempat terhindar dari gharar, yang kelima tidak melakukan penimbunan barang, selanjutnya yang keenam yaitu tidak melakukan al-ghabn dan tadlis, yang terakhir yaitu saling menguntungkan, prinsip ini mengajarkan bahwa dalam bisnis atau jual beli, para pihak harus merasa untung dan puas.

Berdasarkan observasi awal di daerah Kecamatan Karang Baru khususnya di desa Medang Ara, mayoritas masyarakatnya berpenghasilan dari bertani atau berkebun.Selain bercocok tanam dan bersawah, petani melakukan aktivitas deres getah karet.Karet merupakan bisnis usaha bidang pertanian, dimana petani menyadap pohon karet yang ditampung pada wadah untuk mengumpulkan getah karet tersebut. Dari aktivitas tersebut muncullah transaksi jual beli antar petani karet dengan agen. Di dalam jual beli ini petanilah yang berperan sebagai penjual dan agen berperan sebagai pembeli.

Dari observasi tersebut peneliti melihat bahwa adanya indikasi kecurangan atau penyimpangan terhadap jual beli karet antara agen dan petani karet dalam menjalankan aktivitas jual beli karet, terutama dalam hal pembayaran.Pelanggaran etika bisnis Islam seperti pembulatan harga kerap sekali terjadi.Hal ini sering dilakukan agen dalam membayar hasil karet kepada petani. Sebagai contoh dimana jika harga karet $\mathrm{Rp} 6.500 / \mathrm{kg}$, dengan hasil karet petani sabanyak $85 \mathrm{~kg}$, maka uang yang seharusnya diterima petani yaitu sebesar Rp 552.500, namun agen hanya membayar sebesar Rp.552.000, setelah dibulatkan.

Pembulatan tersebut dilakukan oleh agen tanpa meminta persetujuan ataupun menginformasikan terlebih dahulu kepada petani.Sehingga seringkali petani menerima uang yang tidak sesuai dengan harga karet per kilogramnya.Dalam hal ini persoalannya adalah, bahwa pihak agen dianggap telah merugikan petani dengan pembulatan harga pada saat pembayaran, yang sebelumnya tidak ada kesepakatan terlebih dahulu.Penulis melihat bahwa masih terdapatnya penyimpangan yang dilakukan oleh agen dalam pembulatan pembayaran hasil getah karet kepada petani.Oleh karena itu 
penulis tertarik untuk melakukan kajian lebih dalam lagi terakit dengan bagaimana praktik pembulatan harga pada jual beli karet di Desa Medang Ara Kecamatan Karang Baru dan bagaimana analisis etika bisnis Islam terhadap praktik pembulatan harga pada jual beli karet di Desa Medang Ara Kecamatan Karang Baru?

\section{LANDASAN TEORITIS}

\section{Etika Bisnis Islam}

Etika bisnis adalah seperangkat nilai tentang baik, buruk, benar, dan salah dalam dunia bisnis berdasarkan pada prinsip-prinsip moralitas. Dalam arti lain etika bisnis berarti seperangkat prinsip dan norma di mana perilaku bisnis harus komit padanya dalam bertransaksi, berprilaku, dan berelasi guna mencapai tujuan-tujuan bisnisnya dengan selamat. Etika dalam bisnis Islam mengacu pada dua sumber utama yaitu Al-Qur'an dan Sunnah Nabi SAW. Dua sumber ini merupakan sumber dari segala sumber yang ada, membimbing dan mengarahkan semua perilaku individu atau kelompok dalam menjalankan ibadah, perbuatan atau aktivitas umat Islam. Jadi etika bisnis Islam adalah norma dan tuntunan atau ajaran yang menyangkut sistem kehidupan individu dan atau masyarakat dalam menjalankan kegiatan usaha atau bisnis, dimana harus selalu mengikuti aturan yang ditetapkan dalam Islam sebagai acuan oleh siapapun dalam aktivitas bisnis.

\section{Prinsip-prinsip Etika Bisnis Islam}

Pertama, jujur dalam takaran.Jujur dalam takaran ini sangat penting untuk diperhatikan karena masalah kejujuran tidak hanya merupakan kunci sukses seseorang pelaku bisnis menurut Islam.Tetapi etika bisnis modern juga sangat menekankan pada prinsip-prinsip kejujuran.

Kedua, menjual barang yang baik mutunya.Salah satu cacat etis dalam perdagangan adalah tidak transparan Sdalam hal mutu, yang berarti mengabaikan tanggung jawab moral dalam dunia bisnis. Menyembunyikan mutu sama saja halnya dengan berbuat curang dan bohong.

Ketiga, dilarang menggunakan sumpah. Seringkali ditemukan dalam kehidupan sehari-hari terutama di kalangan para pedagang kelas bawah apa yang dikenal dengan obral sumpah. Mereka terlalu mudah menggunakan sumpah dengan maksud untuk meyakinkan pembeli bahwa barang dagangannya benar-benar berkualitas, dengan harapan agar orang terdorong untuk membelinya. Dalam Islam perbuatan semacam itu tidak dibenarkan karena juga akan menghilangkan keberkahan.

Keempat, longgar dan bermurah hati.Dalam transaksi terjadi kontak antara pen- 
jual dan pembeli.Dalam hal ini seorang penjual diharapkan bersikap ramah dan bermurah hati kepada setiap pembeli. Dengan sikap ini seorang penjual akan mendapat berkah dalam penjualan dan akan diminati oleh pembeli. Kunci suksesnya adalah satu yaitu service kepada orang lain. Rasulullah SAW juga menjelaskan bahwa senyum kepada saudara adalah sedekah bagi kita.

Kelima, membangun hubungan baik (Interrelationship) antar kolega.Islam menekankan hubungan konstruktif dengan siapapun, inklud antar sesama pelaku dalam bisnis. Islam tidak menghendaki dominasi pelaku yang satu diatas yang lain, baik dalam bentuk monopoli, oligopoli maupun bentuk-bentuk lain yang tidak mencerminkan keadilan atau pemerataan pendapatan. Sebagaimana juga yang telah dijelaskan oleh Rasulullah SAW bahwa manusia yang menjalin hubungan silaturrahim dengan baik akan dimudahkan rezeki dan dipanjangkan umurnya oleh Allah SWT.

Keenam, tertib administrasi.Dalam dunia perdagangan wajar terjadi praktik pinjam meminjam.Dalam hubungan ini Al-Qur'an mengajarkan perlunya administrasi hutang piutang tersebut agar manusia terhidar dari kesalahan yang mungkin terjadi.

Ketujuh, menetapkan harga dengan transparan.Harga yang tidak transparan bisa mengandung penipuan. Untuk itu menetapkan harga dengan terbuka dan wajar sangat dihormati dalam Islam agar tidak terjerumus dalam riba.Kendati dalam dunia bisnis kita tetap ingin memperoleh prestasi (keuntungan), namun hak pembeli harus tetap dihormati.(Djakfar, 2008: 84-111).

\section{Ketentuan Dasar Etika Bisnis Islam}

\section{Kesatuan (Tauhid)}

Sumber utama etika Islam adalah kepercayaan penuh dan murni terhadap kesatuan Tuhan.Konsep tauhid yang menjadi dasar filosofis ini, mengajarkan dua ajaran utama dalam ekonomi.Pertama, semua sumber daya yang ada di alam ini merupakan ciptaan dan milik Allah secara absolute (mutlak dan hakiki).Manusia hanya sebagai pemegang amanah (trustee) untuk mengelola sumber daya itu dalam rangka mewujudkan kemakmuran dan kesejahteraan kehidupan manusia secara adil.Dalam mengelola sumber daya itu manusia harus mengikuti aturan Allah dalam bentuk syariah Islam.Kedua, Allah menyediakan sumber daya alam sangat banyak untuk memenuhi kebutuhan manusia.Manusia yang berperan sebagai khalifah, dapat memanfaatkan sumber daya yang banyak itu untuk kebutuhan hidupnya. Dalam perspektif teologi Islam, semua sumber daya yang ada, merupakan nikmat Allah yang tak terhitung (tak terbatas) banyaknya (Rivai, 2012: 53-54) 


\section{Keseimbangan (Keadilan)}

Dalam beraktivitas di dunia kerja dan bisnis, Islam mengharuskan untuk berbuat adil, tak terkecuali kepada pihak yang tidak disukai. Pengertian adil dalam Islam diarahkan agar hak orang lain, hak lingkungan sosial, hak alam semesta, dan hak Allah dan Rasulnya berlaku sebagai stakeholder dari perilaku adil seseorang. Semua hak-hak tersebut harus ditempatkan sebagaimana mestinya (sesuai aturan syariah). Tidak mengakomodir salah satu hak di atas, karena dapat menempatkan seseorang tersebut pada kezaliman (Badroen, 2006: 91).

Perilaku kesetimbangan dan keadilan dalam bisnis secara tegas dalam konteks perbendaharaan bisnis (klasik) agar pengusaha muslim menyempurnakan takaran bila menakar dan menimbang dengan neraca yang benar, karena hal itu merupakan perilaku yang terbaik dan membawa akibat yang terbaik pula. Selain itu manusia dalam melakukan transaksi dalam bidang bisnis harus memberikan haknya sesuai dengan hak masing-masing atau berlaku adil (al-'adalah) dan berlandaskan pada syariah Islam. Dalam aksioma ini, para pihak yang melakukan perikatan dituntut untuk berlaku benar dalam mengungkapkan kehendak dan keadaan, memenuhi perjanjian yang telah mereka buat, dan memenuhi segala kewajibannya.

\section{Kehendak Bebas (Ikhtiyar)}

Pengertian kebebasan dalam perspektif ushul figh berarti bahwa dalam mu'amalah Islam membuka pintu seluas-luasnya, dimana manusia bebas melakukan apa saja sepanjang tidak ada nash yang melarangnya. Aksioma ini didasarkan pada kaidah, pada dasarnya dalam mu'amalah segala sesuatu dibolehkan sepanjang tidak ada dalil yang melarangnya.

Dalam pandangan Islam manusia terlahir memiliki kehendak bebas, yakni dengan potensi menentukan pilihan di antara pilihan-pilihan yang beragam. Manusia sebagai khalifah di muka bumi (sampai batas-batas tertentu) mempunyai kehendak bebas untuk mengarahkan kehidupannya pada tujuan pencapaian kesucian diri.Manusia dianugerahi kehendak bebas (free will) untuk membimbing kehidupannya sebagai khalifah.Berdasarkan aksioma kehendak bebas ini, dalam bisnis manusia mempunyai kebebasan untuk membuat suatu perjanjian.Termasuk keleluasan memilih untuk membatalkan akad jual beli (bisnis) atau meneruskan akad jual beli.

\section{Tanggung Jawab}

Kebebasan tanpa batas adalah suatu hal yang mustahil dilakukan oleh manusia karena tidak menuntut adanya pertanggungjawaban dan akuntabilitas. Untuk memenuhi tuntutan keadilan dan kesatuan, manusia perlu mempertanggungjawabkan 
tindakannya. Secara logis aksioma ini berhubungan erat dengan aksioma kehendak bebas.Meskipun kedua aksioma itu merupakan pasangan secara alamiah, tapi itu tidak berarti bahwa keduanya secara logis atau praktis sedemikian terkait sehingga tidak bisa dibedakan satu sama lain.

Islam menaruh penekanan yang besar pada konsep tanggung jawab, tetapi ini bukan berarti kurang memperhatikan kebebasan individu. Justru Islam berusaha menetapkan keseimbangan yang tepat di atas keduanya.Dimana manusia memiliki tanggung jawab atas tindakan-tindakannya terhadap orang lain. Tanggung jawab merupakan suatu prinsip dinamis yang berhubungan dengan perilaku manusia. Bahkan merupakan kekuatan dinamis individu untuk mempertahankan kualitas kesetimbangan dalam masyarakat.

\section{Kebenaran (Kebajikan dan Kejujuran)}

Kebenaran dalam konteks ini selain mengandung makna kebenaran lawan dari kesalahan, mengandung pula dua unsur, yaitu kebajikan dan kejujuran.Kebenaran adalah nilai kebenaran yang dianjurkan dan tidak bertentangan dengan ajaran Islam. Dalam konteks bisnis kebenaran dimaksudkan sebagai niat, sikap dan perilaku yang benar, yang meliputi proses akad (transaksi), proses mencari atau memperoleh komoditas proses pengembangan maupun dalam proses upaya meraih atau menetapkan margin keuntungan (laba).

Kebajikan adalah sikap ihsan, yang merupakan tindakan yang memberi keuntungan bagi orang lain. Dalam Islam sikap ini sangat dianjurkan. Dalam aplikasinya, menurut Al-Ghazali terdapat tiga prinsip kebajikan, yakni pertama, memberi kelonggaran waktu pada pihak terutang untuk membayar utangnya. Dan jika perlu mengurangi beban utangnya.Kedua, menerima pengembalian barang yang telah dibeli. Ketiga, membayar utang sebelum waktu penagihan tiba.

Termasuk ke dalam kebajikan dalam bisnis adalah sikap kesukarelaan dan keramahtamahan. Kesukarelaan dalam pengertian, sikap sukarela antara kedua belah pihak yang melakukan transaksi, kerja sama, atau perjanjian bisnis. Kedua belah pihak sama-sama mempunyai hak pilih atas transaksi dan tidak boleh bersegera memisahkan diri untuk menjaga jika ada ketidak cocokan bahkan pembatalan transaksi. Keramah tamahan merupakan sikap ramah, toleran baik dalam menjual, membeli maupun menagih. Adapun kejujuran adalah sikap jujur dalam semua proses bisnis yang dilakukan tanpa adanya penipuan sedikit pun. Sikap ini dalam khazanah Islam dapat dimaknai dengan amanah (Fauroni,2006:151-157) 


\section{Pembulatan Harga}

Harga hanya terjadi pada akad, yakni sesuatu yang direlakan dalam akad, baik lebih sedikit, lebih besar, atau sama dengan nilai barang. Biasanya, harga dijadikan penukar barang yang diridhoi oleh kedua pihak yang berakad.Mekanisme penentuan harga secara Islami berorientasi pada diperolehnya tingkat kesejahteraan yang sepadan sesuai dengan kontribusi setiap pihak dan tidak mengarah pada ketidakadilan dalam memperoleh nilai tambah ekonomi bagi pihak-pihak terkait (Muslich, 2007: 156).

Menurut Ibnu Taimiyah yang dikutip oleh Qardhawi, penentuan harga mempunyai dua bentuk, ada yang boleh, dan ada yang haram.Tas'ir ada yang zalim, itulah yang diharamkan dan ada yang adil, itulah yang dibolehkan.Selanjutnya Qardawi manyatakan bahwa jika penentuan harga dilakukan dengan memaksa penjual menerima harga yang tidak mereka ridhoi, maka tindakan ini tidak dibenarkan oleh agama. Namun jika penentuan harga itu menimbulkan suatu keadilan bagi seluruh masyarakat, seperti menetapkan Undang-undang untuk tidak menjual di atas harga resmi, maka hal ini diperbolehkan dan wajib diterapkan.

Ada dua tema pembahasan Ibnu Taimiyah tentang masalah harga:

1) Kompensasi yang setara/adil ('Iwad Al-Mitsl) yaitu penggantian sepadan yang merupakan nilai harga yang setara dari sebuah benda menurut adat kebiasaan.

2) Harga yang setara/adil (Tsaman Al-Mitsl) yaitu nilai harga dimana orangorang menjual barangnya dapat diterima secara umum sebagai hal yang sepadan dengan barang yang dijual itu ataupun barang-barang yang sejenis lainnya ditempat dan waktu tertentu.

Landasan keadilan di dalam Islam merupakan landasan utama yang harus dijalankan umat Islam dalam berperilaku, baik dalam konteks terhadap diri sendiri, sesama manusia dan terhadap lingkungan. Di dalam filsafat etika, keadilan ini merupakan asas utama. Hal ini dapat dilihat pada the ethics of Ariestoteles menyatakan keadilan adalah keutamaan yang sempurna dan tidak bersifat pribadi karena ia berkaitan dengan banyak orang atau masyarakat. Harga yang tidak transparan bisa mengandung penipuan.Untuk itu menetapkan harga dengan terbuka dan wajar sangat dihormati dalam Islam agar tidak terjerumus dalam riba.Maka dari itu persoalan harga harus dijelaskan secara benar dan transparan, untuk terciptanya keadilan dalam harga, sehingga tidak ada pihak yang merasa dirugikan (Djakfar, 2008: 114). 


\section{Jual Beli}

Perkataan jual beli terdiri dari dua suku kata yaitu jual dan beli. Sebenarnya kata jual dan beli mempunyai arti yang satu sama lainnya bertolak belakang. Kata jual menunjukan bahwa adanya perbuatan menjual, sedangkan beli adalah adanya perbuatan membeli. Dengan demikian perkataan jual beli menunjukan adanya dua perbuatan dalam satu peristiwa, yaitu satu pihak menjual dan pihak lain membeli, maka dalam hal ini terjadilah peristiwa jual beli.

Jual beli menurut etimologi berarti menukar harta dengan harta. Sedangkan menurut terminologi fiqh jual beli disebut dengan al-ba'i yang berarti menjual, mengganti dan menukar sesuatu dengan sesuatu yang lain. Sehingga dapat dipahami bahwa inti jual beli adalah suatu perjanjian tukar menukar benda atau barang yang mempunyai nilai secara sukarela di antara kedua belah pihak, yang satu menerima benda-benda dan pihak lainnya menerimanya sesuai dengan perjanjian atau ketentuan yang telah dibenarkan syara' dan disepakati (Suhendi, 2008: 68).

\section{Prinsip-prinsip dalam Jual Beli}

Apapun bentuk perdagangan dalam yang dilakukan seseorang selama tidak lepas dari kendali nilai-nilai tersebut dibenarkan dalam Islam, demikian pula Islam mendukung perdagangan yang membawa manfaat apapun untuk kesejahteraan manusia dengan tetap mendasarkan diri pada prinsip Islam. Dalam Islam prinsip dalam perdagangan selain kejujuran dan kepercayaan juga diperlukan prinsip lain, seperti:

a. Tidak melakukan sumpah palsu.

Sumpah palsu biasanya dilakukan pedagang dewasa ini dengan motif dan tujuan untuk meyakinkan konsumen bahwa barang dan jasa yang diperdagangkannya tidak demikian. Dengan cara yang demikian timbullah ketidakjujuran dan sikap acuh seseorang terhadap nilai moral dalam transaksi perdagangan.

b. Adil dalam takaran dan timbangan

Konsep keadilan harus diterapkan dalam mekanisme pasar.Hal tersebut dimaksudkan untuk menghindari praktik kecurangan yang dapat mengakibatkan kedazaliman bagi suatu pihak.Dalam perdagangan, nilai timbangan dan ukuran yang tepat dan standar benar-benar harus diutamakan. Islam meletakkan penekanan penting dari faedah yang memberikan timbangan dan ukuran yang benar (Imaniyati,2002: 169).

c. Kejujuran dalam bertransaksi.

Syariah Islam sangat memperhatikan nilai-nilai kejujuran dalam bertransaksi, 
seperi penjelasan penjual atas cacat barang yang dijual.Apabila dalam barang dagangan terdapat kerusakan dan penjual tidak memberi penjelasan kepada pembeli, maka penjual telah melakukan pelanggaran syariah. Memberikan hak kepada pembeli untuk mengembalikan barang ketika terdapat kerusakan, memberikan hak untuk membatalkan transaksi ketika ditemukan kerusakan yang dapat mengurangi nilai intrinsik sebuah komoditas, serta memberikan kebebasan dalam memilih.

\section{d. Konsep kemudahan dan kerelaan}

Kesepakatan dan kerelaan merupakan pondasi dasar dalam melakukan transaksi.Setiap transaksi yang dilakukan harus mencerminkan keridhoan dan kerelaan masing-masing pihak dalam menentukan beberapa kesepakatan dalam bertransaksi.

e. Menetapkan harga dengan transparan

Harga yang tidak transparan bisa mengandung penipuan. Untuk itu menetapkan harga secara terbuka dan wajar sangat dihormati dalam Islam agar tidak terjerumus dalam riba.

f. I'tikad yang baik.

l'tikad yang baik dalam perdagangan dianggap sebagai hakikat perdagangan. Sebab hubungan buruk yang timbul dalam dunia bisnis dan perdagangan disebabkan karena tidak adanya i'tikad baik yang timbul dari belah pihak.l'tikad yang baik dalam perdagangan dipandang sentral dalam Ekonomi Islam sehingga di dalam Al-Qur'an terdapat perintah yang jelas untuk membina hubungan baik dalam usaha.

g. Adanya hak pilih (khiyar)

Dalam jual beli dalam Islam diperbolehkan untuk memilih (khiyar), apakah meneruskan atau membatalkan jual beli (Muhammad, 2007: 105-110).

\section{METODE}

Dalam penelitian ini peneliti menggunakan penelitian lapangan (field research) yaitu kegiatan penelitian yang terkait tentang analisis etika bisnis Islam terhadap praktik pembulatan harga pada jual beli karet di desa Medang Ara Kecamatan Karang Baru. Pendekatan yanh digunakan dalam penelitian ini adalah pendekatan kualitatif. Menurut Supardi (2005) penelitian kualitatif adalah pengumpulan data pada suatu latar alamiah.

Adapun lokasi penelitian ini adalah di desa Medang Ara Kecamatan Karang Baru. Dikarenakan keterbatasan peneliti dalam observasi ke lokasi penelitian atau wawancara masyarakkat secara menyeluruh, peneliti membatasi hanya 8 orang yang 
terdiri dari 1 orang agen karet dan 7 orang petani karet yang mewakili seluruh responden yang dibutuhkan karena penelitian ini dilakukan dengan wawancara mendalam.

\section{HASIL DAN PEMBAHASAN}

Praktik Pembulatan Harga pada Jual Beli Karet di Desa Medang Ara Kecamatan Karang Baru

Dalam jual beli karet, agen banyak melakukan pembulatan harga.Pembulatan harga yang dilakukan agen adalah pembulatan harga ke bawah. Artinya ketika petani menjual $55 \mathrm{~kg}$ karet kepada agen dengan harga Rp 6.500 maka uang ya g seharusnya diterima petani adalah Rp 357.500, namun hanya dibayarkan agen sebesar Rp 357.000. Pembulatan ini dilakukan agen karena tidak adanya uang receh untuk membayar karet petani, dan agen merasa petani akan mengerti dan ikhlas dengan hal tersebut.

Dalam hal ini agen mengira bahwa para petani telah mengetahui pembulatan harga tersebut dan akan ikhlas dengan hal itu, padahal ia tidak pernah menanyakan langsung kepada petani. Ini berarti agen mengira-ngira sesuatu yang tidak pasti (gharar), sesuatu yang hanya diketahui oleh Allah swt.Gharar ini adalah sesuatu yang dilarang dalam etika bisnis Islam karena merupakan hal yang zalim yang dapat menimbulkan ketidakadilan bagi salah satu pihak.

Berdasarkan pengalaman salah seorang petani karet yaitu bapak Arifin, ketika ia menjual karetnya sebanyak $93 \mathrm{~kg}$ dengan harga yang dibeli agen yaitu $\mathrm{Rp} 6.500$ per kilogramnya, maka uang yang seharusnya diterima bapak Arifin yaitu sebesar Rp 604.500, namun pada kenyataannya hanya dibayarkan oleh agen sebesar Rp 604.000. Bapak Arifin merasa bingung terkait dengan hal tersebut, dikarenakan agen juga tidak meminta persetujuan terlebih dahulu jika uangnya dibulatkan. Sebagai penjual bapak Arifin merasa kurang puas dengan hal ini karena adanya ketidakadilan atas uang yang ia terima.

Sesuai dengan hal tersebut, maka pebulatan harga lebih baik tidak dilakukan karena akan merugikan salah satu pihak, dan hal ini tidak sesuai dengan etika bisnis dalam Islam. Apabila memang karena tidak adanya uang receh, maka akan lebih baik jika pembulatan harga ini tidak dilakukan. Para pebisnis khususnya agen karet seharusnya menerapkan salah satu sifat yang diajarkan Rasulullah saw yaitu ta'awud (tolong-menolong), yaitu dengan tidak membulatkan harga karet kebawah, namun keatas. Maka dengan begitu agen tidak mengurangi jumlah uang yang seharusnya dibayarkan kepada petani, namun justru menambahnya. Dengan begitu maka para petani atau penjual karet akan sangat ridho dan senang dengan pihak agen yang 
melakukannya, sehingga mereka akan tetap tertarik untuk menjual karet tersebut kepada agen.

Jika pembulatan harga ini dilakukan karena alasan tertentu seperti sulitnya mendapatkan uang receh. Ini berarti pihak agen mengira-ngira hati para petani, karena sesungguhnya tidak semua petani akan ikhlas dengan pembulatan harga tersebut. Hal ini jelas adalah sesuatu yang gharar, sedangkan sesuatu yang gharar tidak dibolehkan dalam etika bisnis Islam. Maka dalam hal ini seharusnya ada transparansi bahkan dialog antara agen dan petani tentang kekurangan uang dalam pembayaran tersebut. Apakah uang tersebut mau diikhlaskan atau mungkin ditukaran dengan barang yang nilainya sama. Karena hal yang ditakutkan adalah pembulatan harga ini nantinya akan menjadi pedoman dikalangan pebisnis umumnya dan agen karet khususnya yang tidak dihiraukan dalam jual beli.

\section{Analisis Etika Bisnis Islam terhadap Praktik Pembulatan Harga pada Jual Beli Karet di Desa Medang Ara Kecamatan Karang Baru}

Seluruh kegiatan muslim tidak boleh semata-mata hanya berorientasi pada sejumlah keuntungan material yang diperoleh, melainkan juga harus memperhatikan aturan-aturan atau nilai etika yang dianjurkan oleh syariah Islam. Baik yang berkaitan dengan tujuan dan motivasi bekerja, cara menjalankannya, maupun dalam hal penggunaan hasil kerja yang diperoleh dari setiap pekerjaannya. Agar dapat melaksanakan kegiatan ekonomi dengan sukses dan sejalan dengan syariah, maka seseorang muslim harus memiliki pengetahuan dan keterampilan di dunia usaha, memahami berbagai aturan, prinsip-prinsip dan pesan-pesan moral syariat terkait dengan kegiatan perekonomian.

Maka dari pada itu didalam berbisnis harus dilandasi oleh etika bisnis Islam baik aturan-aturan, maupun ketentuan dasar dalam berbisnis.Adapun ketentuan dasar tersebut adalah kesatuan (Tauhid), keseimbangan (keadilan), kehendak bebas (Ikhtiyar), tanggung jawab (Fardh), kebenaran (kebajikan dan kejujuran).

1. Kesatuan (Tauhid)

Pihak agen karet melakukan pembulatan harga terhadap uang pembayaran jual beli karet kepada petani tanpa adanya pemberitahuan sedikitpun. Ketika petani menjual karetnya sebanyak 67 kg dengan harga Rp 6.500 per kilogramnya, maka uang yang seharusnya diterima petani adalah Rp. 435.500, namun agen hanya membayar sebesar Rp. 435.000 setelah dibulatkan. Hal ini berarti agen mengurangi uang yang seharusnya diterima petani, walaupun dalam nominal kecil. Dengan begitu agen juga berlaku semena-mena atau tidak mementingkan petani untuk mendapatkan apa yang menjadi haknya, yaitu keseluruhan uang atas penjual karet miliknya. Sehingga 
menyebabkan petani merasa tidak puas dan merasa tertindas.Pembulatan tersebut dapat menyebabkan hilangnya rasa persaudaraan antar sesama manusia umumnya dan antar pelaku bisnis khususnya.

Jadi pembulatan harga yang dilakukan pihak agen tidak sesuai dengan ketentuan dasar etika bisnis Islam yaitu dalam hal kesatuan (Tauhid), karena merupakan perbuatan yang dzalim yang dapat menyebabkan hilangnya rasa persaudaraan serta persatuan antara pelaku bisnis.

\section{Keseimbangan (Keadilan)}

Ketika harga karet Rp 6.500 per kilogramnya, dan petani menjul karetnya sebanyak $127 \mathrm{~kg}$, kemudian agen membayarnya sebesar Rp 825.000 setelah dibulatkan. Dimana seharusnya agen membayar sebesar Rp 825.500, hal ini dilakukan tanpa ada konfirmasi dari agen kepada petani.Ini berarti agen berlaku tidak adil karena tidak memberitahukan terlebih dahulu tentang jumlah uang yang dibulatkan, pihak agen telah mencurangi petani dan tidak memberikan keseluruhan jumlah uang yang seharusnya diterima petani.

Berlaku curang atau tidak adil dalam jual beli seperti halnya yang dilakukan oleh agen karet tersebut dilarang oleh agama Islam. Ibnu Taimiyah juga berpendapat bahwa penentuan harga yang tidak adil (zalim) dan penentuan harga yang memaksa pembeli menerima harga yang tidak mereka ridhoi, itu tidak dibenarkan oleh Agama. Karena hal tersebut dapat menimbulkan salah satu pihak terzolimi dan tidak ridho seperti kejadian pada jual beli karet di Desa Medang Ara.Jadi Pembulatan harga yang dilakukan oleh agen tidak sesuai dengan ketentuan dasar etika bisnis Islam dalam hal keseimbangan (keadilan), karena transaksi tersebut menjadi tidak setara atau merugikan salah satu pihak yaitu petani karet.

\section{Kehendak Bebas (Ikhtiyar)}

Pembulatan harga oleh agen dilakukan tanpa ada konfirmasi atau pemberitahuan terlebih dahulu kepada petani, sehingga menyebabkan petani merasa dicurangi dan dirugikan.Agen yang tidak memberitahukan adanya pembulatan ini secara tidak langsung telah melakukan pemaksaan kepada petani, dimana setelah bon dan uang diterima oleh petani, penani justru harus menerima adanya pembulatan tersebut. Maka dalam hal ini terkesan otoriter, artinya agen tidak menghiraukan hak petani yaitu mendapatkan kebebasan untuk mengetahui uang yang seharusnya diterima oleh petani. Kebebasan merupakan bagian penting dalam nilai etika bisnis Islam, tetapi kebebasan tersebut tidak merugikan kepentingan orang lain. Jadi, pembulatan harga yang dilakukan oleh agan tersebut tidak sesuai dengan salah satu ketentuan dasar dalam etika bisnis Islam yaitu kehendak bebas (ikhtiyar). 


\section{Tanggung Jawab}

Pembulatan harga yang dilakukan agen karena tidak adanya uang receh dan agen merasa uang receh saat ini sudah tidak dibutuhkan lagi oleh petani, sehingga mereka akan ikhlas dengan uangnya yang dibulatkan. Tetapi kenyataannya banyak petani yang merasa kurang puas dengan hal tersebut, karena mereka merasa agen tidak bertanggung jawab terhadap uang mereka. Dalam hal ini memang benar bahwa agen tidak bertanggung jawab karena telah mengambil uang petani walaupun dalam nominal yang kecil. Ketika jumlah karet yang dibeli sebesar Rp 825.500, agen hanya membayar sebesar Rp 825.000, berarti ada pengurangan terhadap uang tersebut sebesar Rp.500. Seharusnya jika tidak ada uang receh untuk membayarnya, agen harus bertanggung jawab dengan uang tersebut dengan cara yang diperbolehkan, seperti menggantinya dengan barang yang nilainya sama atau menerapkan sifat tolong menolong dengan cara membulatkan keatas, bukan kebawah.

Dari uraian diatas, pembulatan harga yang dilakukan oleh agen bertentangan dengan ketentuan dasar etika bisnis Islam yaitu dalam hal tanggung jawab, dimana kebijakan pembulatan harga ini terkesan disembunyikan dari petani.Agen tidak bertanggung jawab untuk membayar keseluruhan uang pembelian karet dari petani, sehingga petani menerima uang yang tidak sesuai dari penjualan karetnya.

5. Kebenaran (Kebajikan dan keadilan)

Dalam melakukan pembulatan harga, agen tidak pernah menginformasikan kepada petani terkait adanya pembulatan harga tersebut dan ketika membayar, agen tidak menuliskan jumlah uang yang sebenarnya di bon pembelian karet tersebut.Agen menuliskan jumlah uang penjualan karet setelah dibulatkan. Misalnya pada harga karet Rp 6.500 per kilogramnya, dengan jumlah karet petani sebanyak $145 \mathrm{~kg}$, tetapi di bon pembayaran agen menuliskan jumlah uangnya sebesar Rp.942.000, dimana seharusnya yaitu sebesar Rp.942.500. Maka hal ini berarti suatu kebohongan atau ketidakjujuran. Seharusnya agen memberitahukan yang sebenarnya agar petani tidak merasa heran dan merasa puas sehingga terjadi transaksi yang suka sama suka, artinya tidak ada pihak yang merasa dirugikan.

Jadi berdasarkan konsep kebajikan, seharusnya pihak agen membantu petani untuk tidak membulatkan uang pembelian karet petanin kebawah, namum membulatkannya keatas. Sehingga petani akan sangat senang dan membuat jual beli tersebut menjadi lebih berkah serta sesuai dengan konsep kebajikan. Tetapi karena sebaliknya, pembulatan harga yang dilakukan oleh agen tersebut bertentangan dengan ketentuan dasar etika bisnis Islam yaitu tidak sesuai dengan kebenaran yang didalamnya terdapat unsur kebajikan dan kejujuran. 


\section{SIMPULAN}

Praktik pembulatan harga yang dilakukan agen karet desa Medang Ara adalah pembulatan harga yang kebawah. Artinya ketika petani menjual karet sebanyak 127 kg dengan harga karet Rp 6.500 per kilogramnya, maka yang seharusnya dibayarkan oleh agen adalah Rp 825.500, namun agen hanya membayar Rp 825.000 setelah dibulatkan. Hal ini dilakukan agen tanpa meminta persetujuan ataupun menginformasikan terlebih dahulu kepada petani.Sehingga seringkali petani menerima uang yang tidak sesuai dengan yang seharusnya dibayarkan oleh agen. Alasan agen melakukan pembulatan ini adalah karena ketiadaan uang receh yang membuat sulitnya dalammembayar karet tersebut, dan agen mengira pembulatan ini adalah hal yang lazim dan sudah diketahui oleh para petani, sehingga petani akan ikhlas jika uangnya dibulatkan.

Pembulatan harga yang dilakukan agen karet desa Medang Ara bertentangan dengan ketentuan dasar dalam etika bisnis Islam yaitu kesatuan, keseimbangan, kehendak bebas, tanggung jawab, dan kebenaran.Selain itu pembulatan harga ini juga bertentngn dengan prinsip-prinsip dalam etika bisnis Islam seperti kejujuran dan transparansi dalam menetapkan harga.

\section{PUSTAKA ACUAN}

Badroen, Faisal. (2006). Etika Bisnis Dalam Islam.Jakarta: Prenadamedia Group

Djakfar, Muhammad. (2008), Etika Bisnis Islami Tataran Teoritis dan Praktis. Malang: UIN-Malang Press.

Fauroni, Lukman. (2006). Etika Bisnis dalam Al-Qur'an.Yogyakarta: Pustaka Pesantren

Muhammad. (2004). Etika Bisnis Islami. Yogyakarta: UPP AMP YKPN

Muhammad. (2007).Aspek Hukum Dalam Muamalat. Yogyakarta: Graha Ilmu

Muslich.(2007). Bisnis Syari'ah Perspektif Mu'amalah dan Manajemen. Yogyakarta: Sekolah Tinggi Ilmu Manajemen YKPN

Rivai, Veithzal. (2012). Islamic Business And Economic Ethics. Jakarta: Bumi Aksara

Suhendi, Hendi. (2008). Figh Muamalah. Jakarta:PT.Raja Grafindo Persada

Supardi. (2005). Metodologi Penelitian Ekonomi dan Bisnis. Jakarta: UII Press Yogyakarta

Tantri, Francis. (2010). Pengantar Bisnis. Jakarta: Rajawali Pres 